\title{
Conception of intuition: From the Western philosophy, science, and religion to traditional Vietnamese philosophical thought
}

\author{
Vu Hao Nguyen - Daniel Slivka - Nadezhda V. Telegina - \\ Natalia A. Zaitseva - Zhanna M. Sizova
}

DOI: $10.18355 /$ XL.2020.13.03.18

\begin{abstract}
Intuition is one of the unique human powers to quickly and directly realize the truth of things without any rational analysis or logical thinking process. However, intuition has not really been properly stressed in Western rationalist philosophy. In this article, based on analyzing some conceptions on intuition in the history of Western philosophy, science and religion, we give some comparative interpretations on intuition from traditional Vietnamese philosophical thoughts, especially Confucianism, Daoism, Buddhism, Zen Buddhism... to show that (1) intuition is a universal term that is valid not only in Western philosophy but also in Eastern philosophy, particularly in Vietnamese philosophical thought; (2) intuition is understood in traditional Vietnamese philosophical thoughts mainly as irrational, mystical intuition, and (3) this view has certain similarities to some irrational conceptions in Western philosophy in the twentieth century and today. Since this topic has been scarcely discussed in the academic literature, especially in terms of East-West comparison, the aim of our study is to offer a comparative analysis of existing views and their historical roots.

Key words: Intuition, Western rationalist philosophy, irrationalism, traditional Vietnamese philosophical thought, Confucianism, Daoism, Buddhism, Zen Buddhism, East-West comparative philosophy
\end{abstract}

\section{Introduction}

When reflecting on knowledge process and cognitive capabilities, one often focuses on sensory knowledge (including sensations, perceptions and representations) and rational knowledge (including concepts, judgment and deduction) as the basic factors determining the process of acquiring of the truth knowledge. These have been the fundamental points in the epistemology of many dominant Western rationalist philosophical theories until today. (Ambrozy, 2014) However, these rationalist theories of knowledge have paid scarce attention to other unique human cognitive abilities, particularly intuition. Since the nineteenth century, Western philosophical irrational theories have emphasized intuition as a special human power. Among them were A. Schopenhauer's Philosophy of life, Henri Bergson's Intuitionalism, Edmund Husserl' Phenomenology, S. Freud's Psychoanalysis, the Existentialism of Martin Heidegger and Jean-Paul Sartre and so on. Many different conceptions of intuition were formed and developed before that in the history of Western philosophy, science and religion, however. Concerning this topic, a series of questions can be asked: What is intuition? How is it related to hunch, premonition, sixth sense, telepathy or religious revelation? What are the main conceptions of intuition in the history of Western philosophy, science and religion? What forms of intuition are there in social life? What are the characteristics of traditional Vietnamese philosophical thoughts on intuition?

In this article, based on analyzing some conceptions of intuition in the history of Western philosophy, science and religion, we give some comparative interpretations on intuition from traditional Vietnamese philosophical thoughts, especially Confucianism, Daoism, Buddhism, Zen Buddhism. We will demonstrate that intuition is a universal term that is valid not only in Western philosophy but also in Eastern philosophy, particularly in Vietnamese philosophical thoughts. Moreover, intuition is 
understood in traditional Vietnamese philosophical thoughts mainly as irrational, mystical intuition. Therefore, this view has some similarities to some irrational conceptions in Western philosophy in the twentieth century and today. Since this topic has been scarcely discussed in the academic literature, especially in terms of EastWest comparison, the aim of our study is to offer a comparative analysis of existing views and their historical roots.

\section{Complementary ways of perceiving intuition}

Intuition is the special human power to perceive truth directly without any logical or proven process of thinking. Intuition is considered to be associated with human hunches, premonition, or "sixth senses." Unlike the indirect cognitive process from sensory knowledge to rational knowledge, intuition is direct knowledge of the truth and the nature of things, so this is the best possibility and the shortest path to gain the truth. In social life, we can mention many different kinds of intuition, such as mathematical intuition, scientific intuition, art intuition, and intuition of belief (belief in direct, obvious things without any doubt).

In everyday life, there are countless different kinds of intuition such as intuition in "love at first sight," intuition in looking for friends, searching for partners, intuition as an ability to make sound decisions in real-world situations without intermediate results, child intuition, female intuition (subtle abilities to sense good or bad things in other people's personalities and souls), business intuition (the ability of an entrepreneur to make sound investment decisions in real estate, securities, business for profit...), the intuition of politicians (when making policies or unique political decisions with certain breakthrough possibilities), etc. One of the common kinds of intuition is safety intuition, when people anticipate the dangers of driving, or when preparing to fly, or when confronted with a natural disaster or war situation (for example, intuition tells a person while driving on a deserted rural road in the dark to drive to the side of the road to prevent a giant subsidence; or intuition tells a passenger not to board to avoid a plane crash), etc. (Orlandi, Pierce, 2019)

Intuition is also often mentioned in a close relationship with special human abilities such as hunch, premonition, sixth sense, and telepathy. (Kondrla, Durkova, 2018) Contrary to logic and rational reasoning, hunch or premonition called the "sixth sense" is the mysterious power of the human being to know something, not through the effects of the senses. It is a special power of human beings - although it does not rely on senses and sensory knowledge - it can make great creativities not only in sciences such as the invention of the periodic law by Mendeleev (1834-1907) or the Laws of Universal Gravitation by I. Newton $(1642-1727)$ or the Theory of Relativity by A. Einstein $(1879$ - 1955) but also in art areas such as the musical works of W.A. Mozart (1756-1791) or Ludwig van Beethoven (1770-1827). Hunch or premonition can be considered as a hypothesis or prediction based on intuition. Hunch or premonition is also a form of intuition. Intuition can also be expressed in a telepathic way (telepathy in the Greek is the feeling from a distance), i.e., a movement of a certain image or a certain meaning from the consciousness of a one to the consciousness of another. Telepathy is often accidental, for example, when parents receive a direct signal of the danger threatening their children.

\section{Intuition in Western Philosophy, Science, and Religion}

Human beings are considered to have two dominant major cognitive powers: intellect and intuition. In human history, there have been situations in which the intellect, as the ability to think in a logical way and understand things, cannot penetrate things to define their nature. Then intuition as the supreme power can play its special role. The problem of intuition has been mentioned by some Western rationalist philosophers such as Plato, Aristotle, R. Descartes, I. Kant, J.G. Fichte, F. W.J. Schelling (etc.), and

XLinguae, Volume 13 Issue 3, June 2020, ISSN 1337-8384, ISSN 2453-711X 
carefully analyzed by so-called 'irrational philosophers' (i.e. existentialists or phenomenologists) such as A. Schopenhauer, H. Bergson, S. Freud, E. Husserl, M. Heidegger, J.-P. Sartre, etc.

Intuition is also one of the important and complex research objects of philosophy. This is a controversial issue in the history of Western philosophy. Until now, there has been no unified concept of intuition because this concept is sometimes understood as rational, sometimes as irrational, unable to be verified by empirical facts.

Even in ancient times, the problem of intuition gained the attention of philosophers such as Plato and Aristotle. Plato considered intuition to be a form of direct knowledge, unexpected and super-sensory insight, or a means to gain absolute knowledge about ideas and the idea world. Plato was one of the first thinkers who mention intellectual intuition as contemplation of ideas, which are considered to be the prototype of things in the world of sensory things or as a direct knowledge type and an unexpected insight. Aristotle asserts that human beings have intellectual intuition as the ability to capture directly and unmistakably the nature of things and understand their essence. (Pietka, 2015)

In the Medieval period, intuition was also a live philosophical topic. In his works "On the Trinity" and "Confessions," Augustin of Hippo Rhegius repeatedly states that, in order to achieve the satisfaction of the soul, the individual does not need to turn to the external senses, but must focus on "Inner feeling" or "understanding" as the character through which the soul feels, exists and thinks. (Godawa, 2015) Augustin offers the idea of God's intuition as a religious revelation to perceive God through the human soul and to know the human soul through God (Le, 2000: 49).

In the Early Modern period, there were philosophical debates about intuition from the position of empiricism and rationalism. Descartes was one of the first modern rationalist philosophers to address intellectual intuition, a topic of interest by other philosophers such as Spinoza, Kant, Fichte, and Schelling, closely related to the concept of man. According to Descartes, intuition is the highest form of reason, and the sign of intuition knowledge is evidentness, clarity, and simplicity. From here, he considers the thesis "I think, therefore I am" as the axiom, a theoretical point that is obvious and can be perceived intuitively. This is the foundation for his whole rationalist philosophical system built on the basis of the deductive method. Acknowledging emotions and passions as the third fundamental phenomenon of human nature, after thinking and movement, Descartes does not consider them as cognitive powers. He regards reason as the only source of reliable knowledge. Descartes writes: "In human reason, there are already first concepts or ideas as seeds of truths perceived by us" (Descartes, 1950: 350). He regards evidentness and clarity as the standard of truth of knowledge acquired intuitively. According to Descartes, intellectual intuition is the necessary cognitive power or "mental activity," which can access to innate transcendental knowledge or witness its truth. (Van de Pitte, 1988) Regarding the nature of intuition, Spinoza asserts that there are three types of knowledge that are suitable for four types of perceptions. Intuitive knowledge is based on the fourth type of perception in which things are perceived through their nature or awareness of their causes (Spinoza, 1957: 325).

In the decades of the late eighteenth and early nineteenth centuries, there was a new philosophical trend that criticized rationalism. One of the important beginnings of this trend was I. Kant's critique of reason, particularly through his trio of critical works. However, rejecting intellectual intuition as human cognitive power, Kant believes that this is why people cannot perceive things-in-themselves, but only their phenomena. According to him, only God, as an infinite being, can have intellectual intuition. In spite of denying the intellectual intuition of human beings, Kant acknowledges space and time as transcendental innate forms and indispensable conditions for sensory intuitions. According to him, human beings cannot perceive things-in-themselves because they do not have intellectual intuition. (Wilson, 1975) 
For Fichte and Schelling, intuition is not passive but active. Fichte also acknowledges the role of intuition but asserts that it is impossible to prove it by concepts and that each person needs to find intuition within himself or herself. According to him, intuition is the event of each individual consciousness; at the same time, it is the universal foundation of philosophy and the basis of activities of the cognitive subject. And F. W. J. Schelling emphasizes the role of intuition and considers intuition to be an act of performing the identity between subject and object. "When the contemplating ego immerses itself into itself, it becomes identified with the contemplated ego." (Schelling 1987, 68). Schelling considers intuition to be a form of full awareness of the absolute. According to him, intuition is "the deepest inner experience, and everything we know about the supersensory world depends on it." (Schelling, 1987: 68)

This criticism of reason and science has led to a unique philosophical trend in Western philosophy since the nineteenth century - the irrationalism. Philosophical irrationalists (F. Jacobi, S. Kierkegaard, etc.) focus on intuitive knowledge instead of rational knowledge. The contribution of irrationalism is to show other capacities apart from human reason, specifically to affirm the existence of irrational perception by intuition or mystic intuition as direct perception (Mahrik et al., 2018; Pavlikova 2018; Martin et al., 2020), in which the world is seen as a unified whole of all forms of existence. For example, A. Schopenhauer sees the world voluntaristically and as representation.

Different from the philosophical trend of classical rationalism and scientism, representatives of the philosophical trend of irrationalism, such as $\mathrm{H}$. Bergson and E. Husserl, emphasize intuition as an irrational inner experience. In his work, "Introduction to Metaphysics," Bergson considers intuition as a special kind of sympathy for the object, as the human universal power attached to life and to the will. Husserl also understands intuition not in such a traditional way, while directing to the consideration or contemplation of intellect as a way of recognizing the world and human beings. Other philosophers such as A. Schopenhauer, M. Scheler, M. Heidegger see intuition as a kind of broader and more dynamic generalization or as a special form of profound, overall, and irrational knowledge which has advantages over logical thinking. Criticizing the creative power of reason and its ability to bring about objective knowledge, Schopenhauer argues that reason itself does not extend human knowledge but only can give knowledge a different form, mainly bring about what can be intuitively perceived to reach the clear and general perception (Schopenhauer, 1998: 166). According to him, the sensation is different from intuition: the sensation is only material for intuition.

However, the limitation of this irrationalism is to refuse rational perception and to absolutize the opposition between intuition and intellect. H. Bergson was one of the first thinkers who mention the possibility of mutual complementarity between rational and intuitive perception. He regards intuition as a manifestation of the biological instinct that is opposed to intellect. On the contrary, Husserl's phenomenology considers intuition in a rationalist view rather than a contrast between intuition and rational perception. Moreover, intuition is considered by him to be the basis for rational perception. Phenomenological intuition is a direct contemplation of pure essences, so it is closer to Descartes's intellectual intuition than to Schelling's superrational mystic intellectual intuition.

This kind of mystical intuition is still of little research interest from a philosophical perspective. In addition, some Western religious theories also mention mystical intuition. They claim that God can only be known directly by intuition through revelation. For example, Friedrich Schleiermacher's doctrine emphasizes the role of sensation associated with intuition in religious experience. (Zalec, Pavlikova 2019) His conception influences many later thinkers, including Ernst Troeltsch, Rudolf Otto,

XLinguae, Volume 13 Issue 3, June 2020, ISSN 1337-8384, ISSN 2453-711X 
and Paul Tillich, who stress the role of intuition in the exclusive dependence on reason or tradition. However, most traditional theological thoughts, especially within Christianity, claim that it is impossible to have access to the full knowledge of God in this life, so it is necessary to have dogmas based on traditional revelation. The Russian philosopher N. O. Lossky also refers to mystical intuition as the ability to reveal God. (Sladek, 2017)

In short, from the conceptions given in the history of Western philosophy, religion, and science, the following major types of intuition can be drawn: sensory intuition, intellectual intuition, irrational intuition, and mystical intuition.

(1) The first is sensory intuition, which consists of sensation and perception, attached to sensory organs and sensory knowledge. It is opposed to intellect and thinking, while it does not completely eliminate the rational elements. However, the truth of the sensory intuition was criticized soon by Parmenides and Zenon, especially by Plato in ancient Greek philosophy and later rejected by Leibniz in early modern German philosophy. Sensory intuition can have different forms of expression in social life, for example in communication at home, at work or in the public places, when the smallest details of the interaction of people create a general impression about the behavior and conduct of others, and this is the basis for forecasting possible events in the future.

(2) The second is the intellectual intuition, i.e., the intuition attached to intellect and reason without the support of senses and sensory perception. The concept of intellectual intuition was given by rationalist philosophers such as Plato, Descartes, Spinoza, Leibniz, etc. According to them, it is the direct knowledge acquired in the activities of intellect or reason. Intellectual intuition is a form of direct intellectual knowledge. Intellectual intuition relies on rational thinking, exploring a large amount of information such as in the case of the scientist Mendeleev who invented the periodic table of chemical elements. The intuition here may have a role as a cognitive method or as a form of social anticipation.

(3) The third is the irrational intuition. This unconscious irrational intuition is understood as an innate biological instinct and as a means to directly point out to the human beings what they need to sustain life. Henri Bergson developed his intuitionalism on the basis of such an understanding that makes intuition as a manifestation of the "momentum of life" into an opposition to intellect, reason, and science.

This is also the unconscious intuition as the first hidden, secret principle for creativity given in Freud's psychoanalysis. Husserl and Meinong argue that philosophy has a duty to describe the nature of everything that appears in consciousness, regardless of whether this nature corresponds to something in the real world or not. (Cocchiarella, 1982) In the existentialism of M. Heidegger and J.P. Sartre, intuition has no longer epistemological characteristics but becomes the mode of human existence, which is irrational, not directed at reason and thought, but into empathy. Neo-Kantian thinkers in the twentieth century, such as H. Cohen, P. Natorp, use the concept of blind, irrational intuition to refer to "experience" (Erfahrung) as the opposite of every thought.

(4) The fourth is mystical intuition. So far, there are some different conceptions and theories about intuition, its nature, and content in an epistemological perspective or in ontological view as something mysterious and super-rational. These conceptions and theories do not reject the ability to grasp truth at the moment. Still, they see intuition as an extremely important moment of the complex and unconscious interaction of emotions, reason, and experience. Mystical intuition is considered to be closely related to religious revelation as a special power of the human being who communicates directly with God and receives truth from God.

In the social aspect, intuition can also be manifested in the mixed form of the aforementioned forms, especially sensory intuition, intellectual intuition, and irrational intuition. This intuition, then, plays an important role in, for example, 
dealing with socio-political issues, such as state management and political power, because it is used by almost every leader consciously or spontaneously. As knowledge arising outside of the ways, forms, and conditions perceived consciously and logically, intuition is a forecasting process that includes ways of solving problems. Intuition is characterized by the speed (sometimes quickly and immediately) of making hypotheses and making decisions when there is not enough rational knowledge.

\section{Vietnamese Traditional Conceptions of Intuition}

In Eastern countries, there were thoughts on intuition very early, even in ancient times, but mainly in the direction of irrational, mystical intuition based on the symbolic interpretation of mystical experiences to assist the intellect to have an intuitive experience at the profound levels of absolute reality. Especially in Vietnam, the thoughts on irrational, mystical intuition are given in various doctrines such as Confucianism, Buddhism, Zen Buddhism, Taoism, etc., mostly imported from China and India into Vietnam and transformed, vietnamized, adapted in the context of Vietnamese culture.

Eastern doctrines and Vietnamese philosophical thoughts are not based on coherent concepts and categories as in Western thinking, but use symbols associated with irrational, mystical intuition of absolute reality. According to these Eastern doctrines and Vietnamese philosophical thoughts, behind the world of existing things or the empirical world of phenomena, there is an absolute transcendent reality as the basis, source, and origin for all forms of the world of experience. This can be seen in some traditional Vietnamese philosophical thoughts such as Confucianism, Buddhism, Zen Buddhism, and Daoism.

First of all, it can be said that Vietnamese Confucianism also mentioned the concept of intuition. In the work "Confucianism," first published by Trung Bac Tan Van in 1930, and republished by the Culture and Information Publishing House in Hanoi in 2001, Tran Trong Kim, one of the major scholars of Vietnamese Confucianism, analyzed the Confucian thought on intuition as a special human power.

Accordingly, the human being is a special product of nature influenced by God as an absolute being. God gives human beings a special intuition to perceive the world, to enjoy the beauty and meaning of the world. Without intuition, the world would be meaningless, like a masterpiece of music or a masterpiece of painting that no one would enjoy (Tran Trong Kim [1930], 2001: 78). Among the secrets of the universe, the human being is considered as the greatest secret, among the secrets of the human being, intuition is considered as the greatest secret. As a human creative and unique power, Intuition helps people understand the world, making them better and different from other animals (Pham, 2019).

According to the Metaphysics of Confucianism (Hinh nhi Thuong hoc), the human being is endowed with the quintessential virtues, and is the harmony of Yin and Yang and of Heaven - Earth - Human being, the convergence of demons and the celestial aura of the five elements. "Heaven and earth give birth to people and endow them with very precious characteristics, i.e., people bear the virtue of heaven and earth. People have completely inherited both the mystical spirit and the temperament of the stars, so they are said to be more spiritual than all things. Thanks to that spirit and temperament, people have the insight to understand all things." (Tran, 2001: 78).

In this view, every born human being is also endowed with a gift "Minh Duc," considered as part of God's nature or God's wisdom intellect, a natural insight power to understands the deepest essence of everything, without using reason for the analysis. This Minh Duc or lucid power called intuition, Conscience, or Tam (Mind) is gained by the induction of Heaven, Earth, and Human Being ("Everything in the universe is united"). The knowledge that intuition brings is authentic, capable of achieving the truth and the nature of things. To have that mystical intuition outside of reason and

XLinguae, Volume 13 Issue 3, June 2020, ISSN 1337-8384, ISSN 2453-711X 
intellect, therefore, at the same time also irrational intuition, people need to maintain a calm and relaxed mind, not letting objects and desires obscure the natural insight. In that sense, the intuition in Confucian thought expresses the close relationship between human beings and God. From a Vietnamese Confucian perspective, intuition is different from intellect as human cognitive power. The knowledge brought about by intellect is prone to mistakes because intellect has the ability to quibble and only aim to consider things from their external manifestations.

Concerning the Confucian conception on the role of the intellect, Tran Trong Kim writes: "Intellect is the ability to reason to know everything. But intellect only knows the nature and form of appearance of things ... Usually, what we say, or draw, is not the spirit anymore. So if we deny intuition as the mind's knowing, and use only intellect, then that often makes us wrong ... The intellect of a person, no matter how smart, is limited, and cannot understand as quickly and deeply as intuition..." (Tran, 2001: 33-34). According to Tran Trong Kim, Confucianism highly appreciates the role of both intellect and intuition as special cognitive powers of human beings. He comments the following: "Intelligent and profound insights are often intuitive, not rational. But once you know something, you must use your intellect to check it out, to know clearly what your intuition knows ... So now you have to use both intuition and reason. Intuition is to know, and the intellect is to control" (Tran, 2001: 35-36). However, Confucianism still emphasizes intuition more than intellect, considering learning mainly through intuition. Tran Trong Kim concludes that by logic, we can prove things; thanks to intuition, we can explore them.

Thus, in Vietnamese Confucian thought, intuition or Minh Duc is understood as primarily in the form of irrational and mystical intuition, which is an integral part of the reason of Heaven or the Wisdom of God. From the above analysis, it can be seen that Vietnamese Confucian thought on intuition is quite unique and undeniable. Intuition in Vietnamese Confucianism seems to be quite close to the irrational intuition in Western philosophy.

Second, it is also possible to talk about Vietnamese Buddhist thought on intuition. According to Vietnamese Buddhism, after meditating continuously for 49 days and nights under the Bodhi tree (Bodhirukkha), Shakyamuni became the enlightened being, the Buddha. He conquered inner obstacles and external demons, including greed, ambitions, love desire, affliction, hatred, anger, hunger, loneliness, etc., always appearing and harassing. On the last night, at the time of the first hours of the day, he turned his mind to enlightened intellectual Intuition, recalling past lives: one life, two lives, three lives to hundreds of thousands of previous lives. He achieved Thien Nhan Minh, i.e., the Heavenly Eye, an insight of God through space and time, not with the naked eye. Thien Nhan is an insight of God, and Minh is bright, clearly visible as during the day. He realized what sentient beings of all shapes and sizes created, what karma rotated in the three realms. From there, he was called Buddha, who awakened in the teachings of Buddhism with three main points: "The Four Noble Truths," "The Twelve Links of Dependent Origination," and "Eightfold Path." According to the Buddhist thought, executing the Noble Eightfold Path, the person who attains the righteous result is liberated (Thich, 2018).

Buddhism recognizes two cognitive levels of intellect: (1) transcendent wisdom, Holy wisdom, Prajna wisdom or Intuition - a high level capable of merging into the absolute; and (2) distinguishable intellect, i.e., capable of reasoning or common empirical perception - a lower level. According to the Diamond Sutta of Buddhism, one of the most influential Mahayana sutras, Intuition or Prajna wisdom, can even be aware of "Nothingness" and the main path of knowledge is nonverbal, transcending all concepts (Nguyen, 2012: 44). In order to have intuition as a special power, the cognitive subject must go against the normal flow of consciousness, "wipe out the consciousness," and perform the meditation cycle according to the Noble Eightfold Path. That has certain similarities with Husserl's Phenomenological Reduction to 
achieve a state of pure consciousness in which intuition can identify phenomena identical to essences. On the other hand, the Buddhist conception on intuition as transcendent wisdom, Holy wisdom or Prajna wisdom, which can merge and grasp the absolute, has some similarities with some conceptions in Western philosophy and religion (Henri Bergson, Friedrich Schleiermacher, Paul Tillich...) on irrational or mystical intuition as a revelation.

Third, in the Vietnamese Zen Buddhism, there is also the thought of intuition. According to Zen Buddhism, the world of phenomena depends on the law of cause and effect, and the law of dependent origination, being constantly moving and changing, understood as "impermanence," "non-self" or real non-existence; Behind this phenomenal world, there is an ultimate, absolute invariant reality, an "immutable true existence," transcending all phenomena and extremes "being - nothingness." This real-world cannot be described by concepts and called non-empirical reality. This reality cannot be grasped or realized by common knowledge or logical thinking. To realize the true nature of this absolute reality and to attain absolute truth, human beings can only use the intuition called Prajna wisdom or Prajna Paramita as the only cognitive tool, but not the intellect.

Without denying the ability to perceive the truth, Zen Buddhism explains that there are two types of truth: relative truth (Samvritisatya) and absolute truth (Paramarthasatya). Relative truth is the truth that can be grasped by the common intellect, called consciousness (Vijnana). And the absolute truth can only be grasped by the intuition - Prajna wisdom through meditation practice. The absolute truth of Zen Buddhism often has religious-spiritual meaning. The cognitive way of it is associated with the ability to grasp reality in the whole, in an inseparable entity, completely different from the means, ways, methods of the common cognitive process from the sensory knowledge to rational knowledge (Hoang, 2005).

In order to have an intuitive capacity to access to the absolute, the cognitive subject must "reverse the cognitive direction and enter the inner world" and must "wipe out the consciousness." The belief enlightened by intuition is expressed in Zen Buddhism as a way of personal cultivation, combining inner mind cultivation with morality in the Eightfold Path. Zen Buddhism considers enlightenment as limits to overcome the common rational perception to return to intuition. Therefore, the Vietnamese Zen Buddhist conception on irrational, mystical intuition (Prajna wisdom) as the only cognitive tool outside intellect and logical thinking to grasp the absolute truth and absolute reality, is relatively close to the concept of intuition as a revelation in some Western philosophical and religious conceptions (Henri Bergson, Friedrich Schleiermacher, Paul Tillich, and others)

Fourth, in Vietnamese Daoism, the conception of intuition is also particularly emphasized. The fundamental concept in Daoism is Dao understood as something absolute and as a way that cannot be perceived by the senses. Dao is considered as a way of life, not a God or a religion. Dao is the way or the path on the journey through life. It is suitable for the terrain and the specific timetable of nature. Any path defined outside the Dao is regarded as false. According to Daoism, the whole universe is steeped in ethics. This pristine cosmic power was once called Tai Hu, Tai Chi, and Tai Di (Thai Hu, Thai Cuc, and Thai Di). It is closely connected with an invisible, formless, and colorless element of the universe from which all things are born. Lao Tzu writes about the agnosia of the Dao in his work "Dao De Jing" (or "Tao Te Ching") as follows: "Dao that can be expressed in words is not a permanent Dao" (Lao Tzu, 1996: 215). Zhuangzi, one of Lao Tzu's most famous disciples, adds: "If you do not know, it is profound; if you know, it is superficial ..." (Chuang, 1995: 69). Dao cannot be perceived by experience, but indirect conclusions about the nature of Dao are possible. Dao is often incompletely translated as a way, as emptiness or as non-existence (nothingness).

XLinguae, Volume 13 Issue 3, June 2020, ISSN 1337-8384, ISSN 2453-711X 
However, the emptiness here is understood not as naked, passive, and inactive emptiness as according to Democritus, but as the development process, when something does not exist anymore. Dao is transcendental, i.e., before experience and cannot be realized by experience or the human senses. Like Buddhism, Daoism does not appreciate the knowledge acquired from logical reasoning. Liberation in Daoism is understood to be liberation from the strict rules of convention. The doubtful attitude of Daoism towards knowledge and reasoning is one of the highlights in Eastern philosophy in general and Vietnamese philosophical thought in particular.

This stems from Lao Tzu's conception that the reasoning abilities of the human intellect can never understand the Dao. This can be seen in the comment of Zhuang Zi: What we consider as known best is not necessarily already known; logic reasoning cannot make people wiser. Daoism overlooks the role of theoretical reasoning and discussion. Accordingly, the dog that barks well is not necessarily a good dog; the one who speaks in an attractive manner is not necessarily a gentle person. Arguments can only be seen as superficial. Daoism believes that all Dao's activities are a continuous interaction between contradicting pairs. Daoism draws two basic rules for human attitude: To achieve something, one has to start with the opposite.

However, Lao Tzu points out the key to enlightenment. Approaching to Dao cannot be done by any action ("vo vi' in Vietnamese or "wu-wei' in Chinese). Vo vi or wuwei is understood in Daoism as "nonaction," "effortless action," "action without intent," or "action following nature." This concept refers to the state of "contemplation" or "meditation" in the Daoist tradition, requiring a conscious effort to empty the whole mind completely, but not filling it with profound knowledge. Accordingly, people can have relaxation and excitement, because it clears from the mind the disturbing sounds of everyday life. It is tranquility and insight that can lead to a lot of spontaneous knowledge or intuition on the Dao. People need to completely wash away the rambling thoughts so that their intuitive knowledge of Dao can be spontaneously expressed. A confused mind will obscure the Dao.

According to Daoism, Dao is not an existing reality, but it is nothingness, so it cannot be approached by experience or rationalist means. Dao is the unity being realized. The world is an expression of Dao as an absolute. The only way towards Dao is direct experience or the experience of mystical intuition outside intellect, in which there is no division between one's own self and the world. Therefore, the irrational, mystical intuition of Dao is considered both as a means and as a purpose.

Therefore, general characteristics of traditional Vietnamese philosophical thought systems, such as Confucianism, Buddhism, Zen Buddhism, and Daoism are (1) the tendency to absolutize the irrational, mystical intuition as special power of people and (2) to emphasize the role of irrational, mystical intuition more than their reasoning or empirical perception. Even under different names such as Minh Duc, Transcendent Wisdom, Holy Wisdom, Mystic Experience, and others, all forms of these Vietnamese thoughts consider irrational, mystic intuition as the highest capability of human beings in approaching to true enlightenment about an Absolute Transcendent Reality. In order to have this irrational, mystical intuition power, people need to train and cultivate it throughout their lives. Through these characteristics, it is possible to identify the similarities of some conceptions in Western philosophy and religion analyzed above with some Vietnamese philosophical thoughts, particularly and with Eastern philosophical thoughts generally on intuition.

\section{Conclusion}

The conception of intuition was formed early in the history of philosophy, science, and religion. As a special and marvelous human ability to realize the nature of things quickly without logical analysis and reasoning, intuition can be regarded as an invaluable gift of creation, capable of supplementing and overcoming the limitations in the traditional approach of reason and intellect, helping humans to transcend all 
other animals. Intuition plays a very important role in social life, in science, art, and everyday life. It is a valuable cognitive tool, with great potential for application.

The term intuition is valid both in Western philosophy and in Eastern philosophy, particularly in Vietnamese philosophical thoughts. Therefore, this term is universal. The conceptions of intuition in the history of Western philosophy, science, and religion mention various types of intuition, such as sensory intuition, intuition, intellectual intuition, irrational intuition, and mystical intuition or their mixed forms. However, in Western countries, due to the habit of overestimating the role of reason, intellect, and science, intuition, despite of being known and respected early in the history of Western philosophy, has not attracted the appropriate research interest in traditional rationalist trends and schools. Since the nineteenth century, in the trends of Western irrationalist philosophy, both atheistic and theistic ones, there has been a tendency to stress intuition as one of the special non-rational cognitive powers of human beings.

For their part, concerning the human cognitive power, traditional Vietnamese philosophical thoughts in particular and Eastern Philosophy in general focus mainly on intuition, especially on irrational, mystical intuition. As analyzed above, traditional Vietnamese philosophical thoughts such as Confucianism, Buddhism, Zen Buddhism, and Daoism mainly pay attention to irrational, mystical intuition as a religious spiritual unique power of human beings. On the other hand, these thoughts tend to underestimate rational perception, absolutizing the opposition between intuition and intellect, and emphasizing the role of intuition. These can be considered as characteristics of the Vietnamese philosophical thought.

Therefore, in a certain sense, it is possible to talk about a closer trend between Western philosophy, science, and religion on the one hand and Eastern philosophy and religion on the other, including traditional Vietnamese philosophical thought, when it comes to understanding and using the various conceptions of intuition. The study of intuitive concepts in the history of Western philosophy, religion, and science and in the philosophical thought tradition in Eastern countries including Vietnam is very important and necessary. It can be considered as the key to explaining many other important issues of Western philosophy, Eastern philosophy and East-West comparative philosophy related to the secrets of traditional culture, society, and religion, including the cultural identities, morals forms of life of social communities, characteristics of religions or beliefs and other socio-cultural aspects.

\section{Acknowledgments:}

This research is funded by Vietnam National University, Hanoi (VNU) under project number QG. 17.02.

The work is performed according to the Russian Government Program of Competitive Growth of Kazan Federal University.

The publication has been supported by the 'Russian Academic Excellence Project 5 100 ' of the I M Sechenov First Moscow State Medical University (Sechenov University).

\section{Bibliographic references}

AMBROZY, M. 2014. Mach, Einstein, Dark Matter and Knowability. In: Journal of Magnetohydrodynamics and Plasma Research, vol. 19, n. 1/2, p. 57-64.

CHUANG, T. 1995. Ле-цзы [Le Tzu]. Trans. from Chinese and with note of V.V. Malyavina. Moscow: Thought Publishing House.

COCCHIARELLA, N. 1982. Meinong reconstructed versus early Russell reconstructed. In: Journal of Philosophical Logic, vol. 11, n. 2, pp. 183-214.

DESCARTES, R. 1950. Избранные произведения [Selected Works]. Moscow: Gospolitizdat. 
GODAWA, M. 2015. Conditioning of Intellect in Christian Contemplation in the Light of Definitions and St. Augustine's Experience. In: Bogoslovni vestnik, vol. 75, n. 3, pp. 525-540.

HOANG, T. T. 2005. Thien phat giao - Nguyen ly va mot so phạm tru co ban [Principles and some basic concepts of Zen Buddhism]. In: Philosophical Journal, vol. 173, n. 10, pp. 25-33. Available online: http://philosophy.vass.gov.vn/nghien-cuutheo-chuyen-de/Phuong-Dong/Thien-phat-giao-Nguyen-ly-va-mot-so-pham-tru-coban-229.html. Accessed on 20 June 2019.

KONDRLA, P. - DURKOVA, E. 2018. Interpersonal relations in ethics of science and technologies. In: Communications - Scientific Letters of the University of Zilina, vol. 20, n. 1, pp. 45-50.

LAO, T. 1996. Дао дэ цзин [Tao de jing / Mystery of the Tao]. The world of "Tao de jing". Moscow: Sphere Publishing House.

LE, T.N. 2000. History of Western philosophy, vol. III. Ho Chi Minh City: Ho Chi Minh City Publishing House.

MAHRIK, T. - KRALIK, R. - TAVILLA, I. 2018. Ethics in the light of subjectivity Kierkegaard and Levinas. In: Astra Salvensis vol. 6, n. 2, pp. 488-500.

MARTIN, J. G. - ROJAS, A.M. - KRALIK, R. 2020. The problem of the 'individual' concept in the Kierkegaard's journals. In: European Journal of Science and Theology, vol. 16, n. 2, pp. 39-46.

MUSHENKO, A.N. 2005. Проблема интуиции в философии [The problem of intuition in philosophy]. Available online: https://studfiles.net/preview/3873883/page:15/. Accessed on November 10, 2018.

NGUYEN, V.K. 2012. Vietnam's intellectual resources - History, current status and prospects. Hanoi: Chinh tri Quoc gia Publishing House.

ORLANDI, L.B. - Pierce, P. 2019. Analysis or intuition? Reframing the decisionmaking styles debate in technological settings. Management Decision. In: Management Decision, vol. 58, n. 1:129-145.

PAVLIKOVA, M. 2018. The power of modern technologies in the fiction of Don DeLillo. In: Communications - Scientific Letters of the University of Zilina, vol. 20, n. 1, pp. 57-60.

PIETKA, D. 2015. The concept of intuition and its role in Plato and Aristotle. In: Organon, vol. 47, n.1, pp. 23-40.

PHAM, V.H. 2019. Plato, Confucius: Two great masters believe in the importance of intuition. Available online: https://www.dkn.tv/khoa-hoc-cong-nghe/plato-khong-tuhai-bac-thay-vi-dai-tin-vao-tam-quan-trong-cua-truc-giac.html. Accessed on June 26, 2019.

SCHELLING, F.V.I. 1987. Сочинения [Works]. Vol.1. Moscow: Thought Publishing House.

SCHOPENHAUER, A. 1998. Мир как воля и представление [The world as a will and a representation]. Minsk: Literature.

SLADEK, K. 2017. Sophiology as a Theological Discipline according to Solovyov, Bulgakov and Florensky. In: Bogoslovni vestnik, vol. 77, n. 1, pp. 109-116.

SPINOZA, B. 1957. Избранные произведения [Selected Works]. Moscow: State Publishing House of Political Literature.

THICH, D.T. 2018. 3 types of intellectual victory that Buddha attained in the enlightenment night. Available online: http://daibaothapmandalataythien.org/3-loaithang-tri-duc-phat-chung-dat-trong-dem-thanh-dao. Accessed on November 10, 2018.

TRAN, T.K. 2001 [1930]. Confucianism. Hanoi: Van hoa Thong tin Publishing House.

VAN DE PITTE, F.P. 1988. Intuition and Judgment in Descartes' Theory of Truth. In: Journal of the History of Philosophy, vol. 26, n. 3, pp. 453-470.

WILSON, K.D. 1975. Kant on intuition. In: The Philosophical Quarterly (1950-), vol. 25 , n. 1 , pp. $247-265$. 
ZALEC, B. - PAVLIKOVA, M. 2019. Civic virtues and functions of religion in public life. In: European Journal of Science and Theology, vol. 15, n. 6, pp. 75-84.

Words: 6910

Characters: 45873 (25,5 standard pages)

Prof. Dr. Vu Hao Nguyen, PhD.

University of Social Sciences and Humanities, Vietnam National University, Hanoi

Faculty of Philosophy

336 Nguyen Trai Str., Thanh Xuan Dictrist, Hanoi

Vietnam

nguyenvuhao@hotmail.com

doc. PhDr. PaedDr. Daniel Slivka, PhD.

Department of Historical Sciences

Greek Catholic Theological Faculty

The University of Presov in Presov

Ul. Biskupa Gojdica 2

08001 Presov

Slovak Republic

daniel.slivka@unipo.sk

Assoc. Prof. Nadezhda V. Telegina, PhD

Institute of Psychology and Education

Kazan (Volga region) Federal University

18 Kremlyovskaya Street

420008 Kazan

Russian Federation

nadya-telegina@yandex.ru

Prof. Natalia A. Zaitseva, Doctor

Department of Hospitality, Tourism and Sports Industry

Plekhanov Russian University of Economics

36 Stremyannyi Pereulok

115093 Moscow

Russian Federation

zaitseva-itig@mail.ru

Prof. Zhanna M. Sizova, Doctor

Department of Urgent and Outpatient Therapy

I.M. Sechenov First Moscow State Medical University (Sechenov University)

8 Trubetskaya Street

119991, Moscow

Russian Federation

sizova-klinfarma@mail.ru 